AJIE - Asian Journal of Innovation and Entrepreneurship

(e-ISSN: 2477-0574 ; p-ISSN: 2477-3824)

Vol. 01, No. 02, May 2016

\title{
PENDAMPINGAN PENYUSUNAN MASTERPLAN SENTRA BATIK DI DUSUN PLALANGAN PENDOWOHARJO SLEMAN
}

\author{
Yulianto Purwono Prihatmaji \\ * Program Studi Arsitektur FTSP Universitas Islam Indonesia \\ prihatmaji@yahoo.com
}

\begin{abstract}
ABSRACT
Special Region of Yogyakarta as a city of Education on October 23, 2014 has been named the World Batik City, by the World Crafts Council (World Craft Council / WCC), in Dongyang, Zhejiang Province, China. This coronation as well as an award will admit it as a work of traditional Indonesian batik, which has become an integral part of a Yogyakarta high artistic value. Besides, the establishment of the World Batik Yogyakarta as the City by the World Crafts Council raised hopes for batik artisans in a number of centers in Yogyakarta batik craft to increasingly develop their region into a tourist village-based craft of batik. The development is expected to boost the economy during this batik artisans who rely only income from the sale of batik. Dusun Plalangan Pendowoharjo Village is one of the District of Sleman batik artisans Sinom Parijotho locations in Sleman with the number reaching 20 batik artisans artisans belonging to groups Ayu Arielle batik. Determination of Hamlet Plalangan as batik center in Sleman make a problem for the group. These problems result from 1). unpreparedness crafters to have a regional or batik showrooms integrated, 2). The inability of artisans in developing regional master plan, 3). Potential inability of artisans in mapping and planning the development of the region. Therefore people need assistance through a program of strengthening human resources, and strengthening the potential exploration area.
\end{abstract}

Keywords: batik, batik centers, planning

\begin{abstract}
ABSTRAKS
Daerah Istimewa Yogyakarta sebagai kota Pendidikan pada tanggal 23 Oktober 2014 dinobatkan sebagai Kota Batik Dunia, oleh Dewan Kerajinan Dunia (World Craft Council/WCC), di Dongyang, Provinsi Zhejiang, Tiongkok. Penobatan ini sekaligus sebagai sebuah penghargaan akan di akuinya batik sebagai karya tradisional Indonesia, yang telah menjadi bagian tak terpisahkan dari Yogyakarta yang bernilai seni tinggi. Disamping itu penetapan Yogyakarta sebagai Kota Batik Dunia oleh Dewan Kerajinan Dunia menumbuhkan harapan bagi perajin batik di sejumlah sentra kerajinan batik di Yogyakarta untuk kian mengembangkan kawasan mereka menjadi kampung wisata berbasis kerajinan batik. Pengembangan tersebut diharapkan bisa mendongkrak perekonomian perajin batik yang selama ini hanya menggantungkan pendapatan dari hasil penjualan batik. Dusun Plalangan Desa Pendowoharjo Kecamatan Sleman merupakan salah satu lokasi perajin batik Sinom Parijotho di Kabupten Sleman dengan jumlah perajin mencapai 20 perajin batik yang tergabung dalam kelompok batik Ayu Arimbi. Penetapan Dusun Plalangan sebagai sentra batik di Kabuapaten Sleman menjadikan permasalahan tersendiri bagi kelompok. Permasalahan tersebut akibat dari 1). ketidaksiapan perajin untuk memiliki kawasan atau showroom batik terpadu, 2). Ketidakmampuan perajin dalam menyusun masterplan kawasan, 3). Ketidakmampuan perajin dalam memetakan potensi dan merencanakan pengembangan wilayah. Maka dari itu masyarakat perlu pendampingan melalui program penguatan sumber daya manusia, dan penguatan penggalian potensi wilayah.
\end{abstract}

Kata kunci: batik, sentra batik, perencanaan 


\section{PENDAHULUAN}

Daerah Istimewa Yogyakarta sebagai kota Pendidikan pada tanggal 23 Oktober 2014 dinobatkan sebagai Kota Batik Dunia, oleh Dewan Kerajinan Dunia (World Craft Council/WCC), di Dongyang, Provinsi Zhejiang, Tiongkok. Penobatan ini sekaligus sebagai sebuah penghargaan akan di akuinya batik sebagai karya tradisional Indonesia, yang telah menjadi bagian tak terpisahkan dari Yogyakarta yang bernilai seni tinggi. Disamping itu penetapan Yogyakarta sebagai Kota Batik Dunia oleh Dewan Kerajinan Dunia menumbuhkan harapan bagi perajin batik di sejumlah sentra kerajinan batik di Yogyakarta untuk kian mengembangkan kawasan mereka menjadi kampung wisata berbasis kerajinan batik. Pengembangan tersebut diharapkan bisa mendongkrak perekonomian perajin batik yang selama ini hanya menggantungkan pendapatan dari hasil penjualan batik.

Di Daerah Istimewa Yogyakarta terdapat beberapa sentra batik, salah satunya berada di Kabupaten Sleman. Batik Sleman memiliki kekhasan motif tersendiri di bandingkan dengan kabupaten lain di Daerah Istimewa Yogyakarta. Batik Sinom Parijotho Salak merupakan motif batik unggulan di Kabupaten Sleman yang memiliki motif utama yang terdiri dari elemen tangkai, daun, bunga Parijotho, daun salak dan bunga salak. Elemen tanaman Parijotho dibuat diagonal dan di selasela diisi dengan motif salak pondoh baik buah maupun daun. Latar belakang motif batik berisi cecek, yakni titik-titik kecil yang tersebar merata.

Parijotho sendiri sebenarnya sebuah nama tanaman yang banyak tumbuh dilereng gunung Merapi. Tanaman ini diklaim sebagai tanaman asli kabupaten Sleman. Tanaman ini juga memiliki banyak manfaat dan memiliki khasiat. Berdasarkan uraian tersebut, makna pada batik Sinom Parijotho Salak, khususnya motif Parijotho melambangkan kemakmuran dan salak pondoh merupakan tanaman yang asli dan representasi Kabupaten Sleman.

Dusun Plalangan Desa Pendowoharjo Kecamatan Sleman merupakan salah satu lokasi perajin batik Sinom Parijotho di Kabupten Sleman. Dusun yang terletak $\pm 3 \mathrm{~km}$ utara Kabupaten Sleman ini memiliki 20 perajin batik yang tergabung dalam kelompok batik Ayu Arimbi (lihat Gambar 1). Keahlian membatik perajin berawal dari usulan program indikatif kecamatan tahun 2012 yang di usulkan ke Dinas Perindustrian, Perdagangan dan Koperasi (Disperindagkop) Kabupaten Sleman untuk di latih dan di jadikan sebagai mitra binaan.

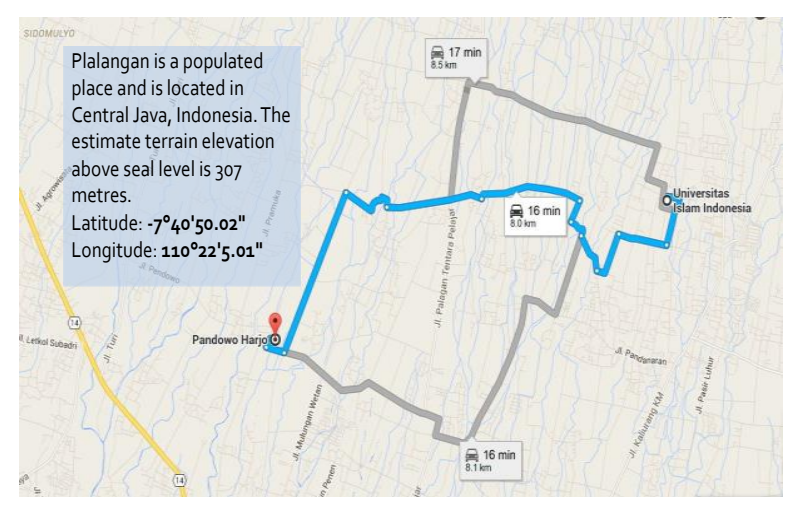

Gambar 1. Lokasi dusun Plalangan

Kelompok batik Ayu Arimbi saat ini telah berkembang pesat baik dari segi produksi maupun pemasaran produk. Produksi yang di hasilkan telah memiliki 40 motif batik, sedangkan untuk pemasaran telah mencapai luar kota Yogyakarta yang meliputi Jakarta, Semarang, Surabaya, Bali, Sumatera, dan Kalimantan (wawancara dengan pengelola, 2015) (lihat Gambar 2).

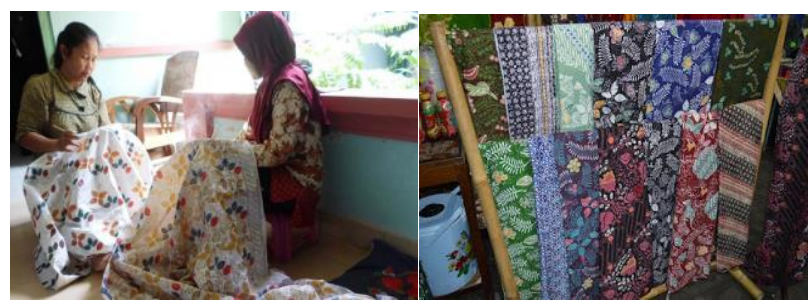

Gambar 2. Batik Sinom Parijotho Plalangan 
Tumbuh kembangnya kerajinan Batik Ayu Arimbi yang berkembang sangat pesat menjadikan perhatian tersendiri bagi pemerintahan di Kabupaten Sleman melalui Disperindagkop. Perhatian tersebut diwujudkan salah satunya di tetapkannya Dusun Plalangan sebagai salah satu sentra batik di Kabupaten Sleman pada bulan november 2015. Kegiatan yang telah di lakukan dalam mendukung penetapan sentra batik tersebut di antaranya adalah: 1). Penguatan kelembagaan melalui pendirian koperasi, 2). Tata kelola limbah batik, 3). Motif dan pewarnaan alami, 4) Pendirian showroom kerajinan (lihat Gambar 3).

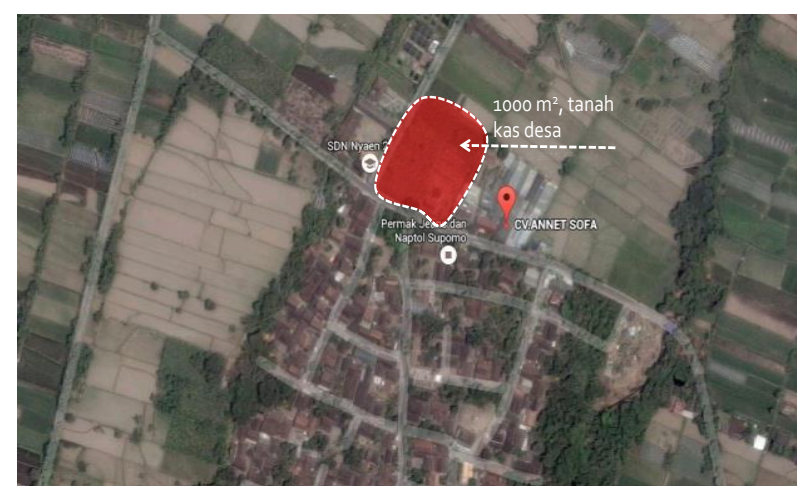

Gambar 3. Rencana lokasi workshop batik

Penetapan sentra batik di Dusun Plalangan menjadikan permasalahan tersendiri bagi perajin, hal ini akibat dari ketidaksiapan perajin dalam menyongsong Dusun Plalangan di jadikan sebagai sentra batik. Permasalahan tersebut di antaranya adalah: 1). ketidaksiapan perajin untuk memiliki kawasan atau showroom batik terpadu, 2). Ketidakmampuan perajin dalam mengelola limbah terpadu, 3). Ketidakmampuan perajin dalam menyusun masterplan kawasan, 4). Ketidakmampuan perajin dalam memetakan potensi wilayah.

Program yang sporadis dan tidak berkelanjutan menjadikan permasalahan ini menjadi permasalahan yang harus segera di atasi. Diharapkan tahun 2016 sentra batik di Dusun Plalangan Pendowoharjo dapat terwujud menjadi sentra kawasan batik, sehinga memberikan kemudahan proses produksi, pemasaran dan promosi bagi pengunjung dan pembeli batik

\section{METODE KEGIATAN}

Dari permasalahan tersebut diatas Metode kegiatan yang akan dilaksanakan dalam mengatasi permasalahan tersebut diatas adalah sebagai berikut :

1. Observasi secara komprehensif kawasan dusun, potensi obyek kawasan dusun dan simpul-simpul produksi batik.

2. Penggambaran keseluruhan kawasan, bagian kawasan dan komponen kawasan dusun.

3. Pendampingan penyusunan gagasan dan keinginan serta kebutuhan berbasis partisipasi masyarakat, tokoh masyarakat dan perajin batik.

4. Pendampingan penyusunan pemetaan kawasan, outlet sentra dan masterplan kawasan sentra batik

\section{HASIL DAN PEMBAHASAN}

Dusun Plalangan berada di desa Pandowoharjo kabupaten Sleman, Yogyakarta. Plalangan merupakan dusun yang mandiri yang memiliki berbagai macam potensipotensi alam yang dapat mendukung perkembangan perekonomian masyarakat dan pelestarian alamnya. Plalangan oleh masyarakat dan perangkat dusunnya ingin dikembangkan menjadi destinasi desa wisata budaya yang mengusung konsep kesejahteraan dan kelestarian. Konsep kesejahteraan ini menggambarkan bahwa setiap warga seharusnya dapat saling mengayomi dalam segala hal mulai dari kebutuhan pangan sampai sumber daya lain.

Kunjungan pertama ke dusun Plalangan pada hari senin 25 Januari 2016 pada pukul 09:30 - 12:00 WIB. Dalam pertemuan ini banyak membahas tentang rencana-rencana kedepan dalam mengembangkan potensi-potensi yang ada, seperti batik sebagai salah satu potensi yang juga ingin ditonjolkan di desa tersebut. Dalam 
perbincangan antara tim dengan warga sangat banyak membahas tentang proses membatik, pembuatan batik dan pewarnaan alam yang ingin di terapkan sebagai ciri khas pewarnaan batik di desa tersebut. Selain itu juga membahas tentang pengelolaan limbah dari pewarnaan dan pencucian batik. Tujuannya adalah untuk menemukan solusi pengolahan yang ramah lingkungan. Poin-poin pengembangan desa yang akan di lakukan adalah: pertama, pembuatan Master Plan Dusun Plalangan; kedua, pembuatan tempat pengolahan limbah pembatik; ketiga, pembuatan tempat workshop batik; dan keempat, pembuatan showroom batik. Adapun cita-cita yang lain adalah menjadikan setiap pekarangan memilik tanaman-tanaman buah, menjadi dusun wisata ramah lingkungan, memfasilitasi homestay, dan menjadi sentra batik.

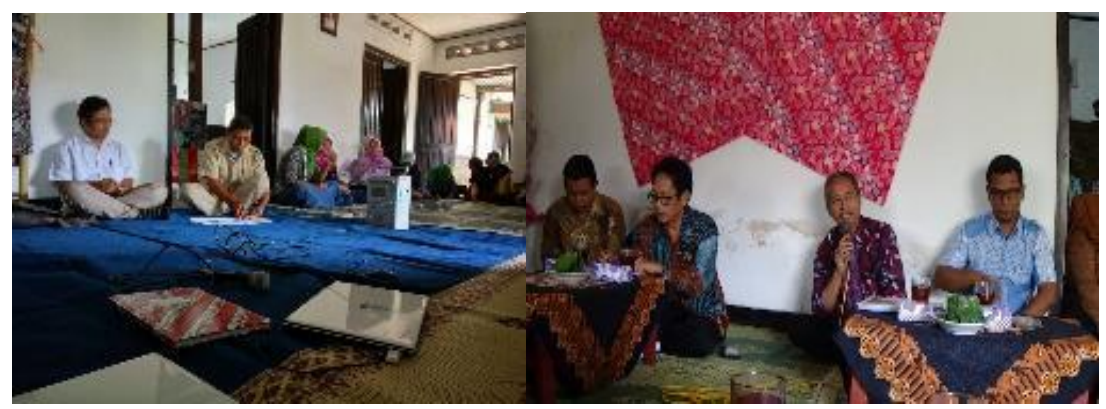

Gambar 4. Observasi dan wawancara dengan kelompok

\section{HASIL OBSERVASI}

Hasil observasi adalah dokumentasi view, keadaan sekitar dan kondisi serta letak pohon-pohon yang ada di dusun Plalangan.
Pola pemukiman, blok bangunan, ruang terbuka letak dan jalur jalan di dusun juga didokumentasikan, seperti terlihat pada gambar 3 .

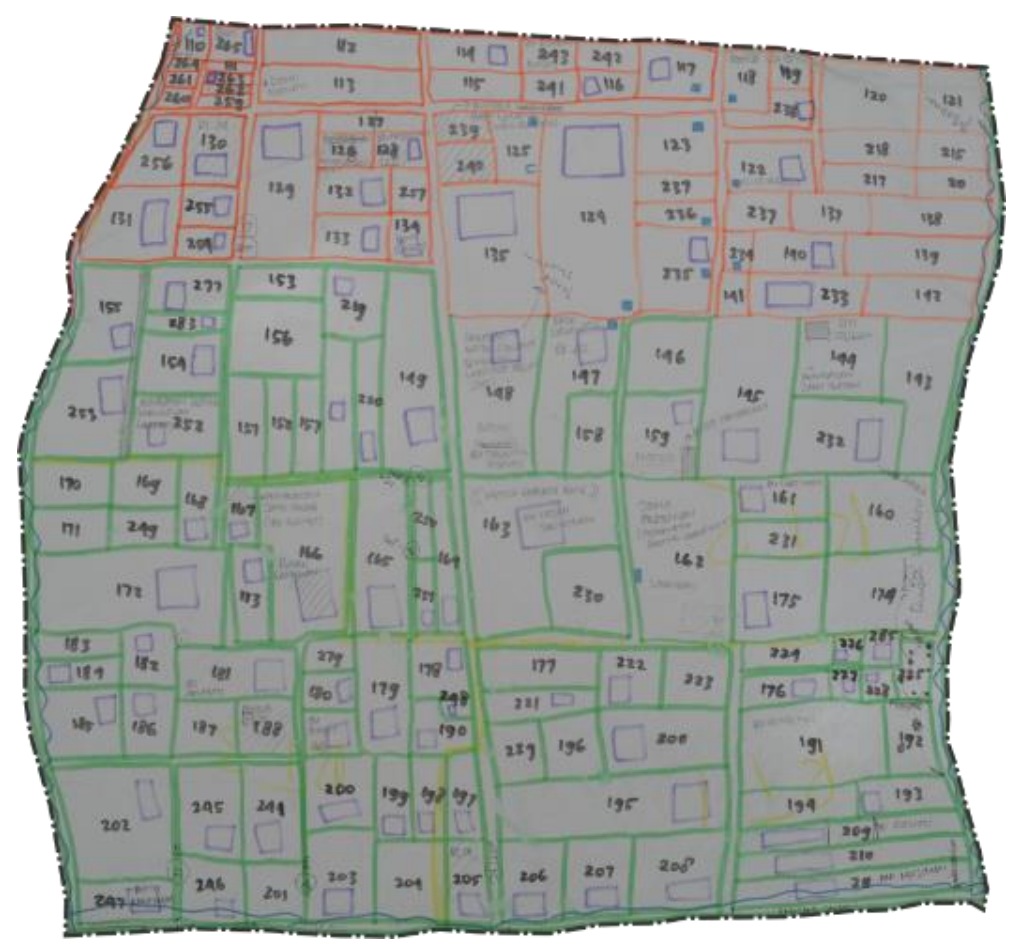

Gambar 5. Peta dusun yang digambar ulang. 


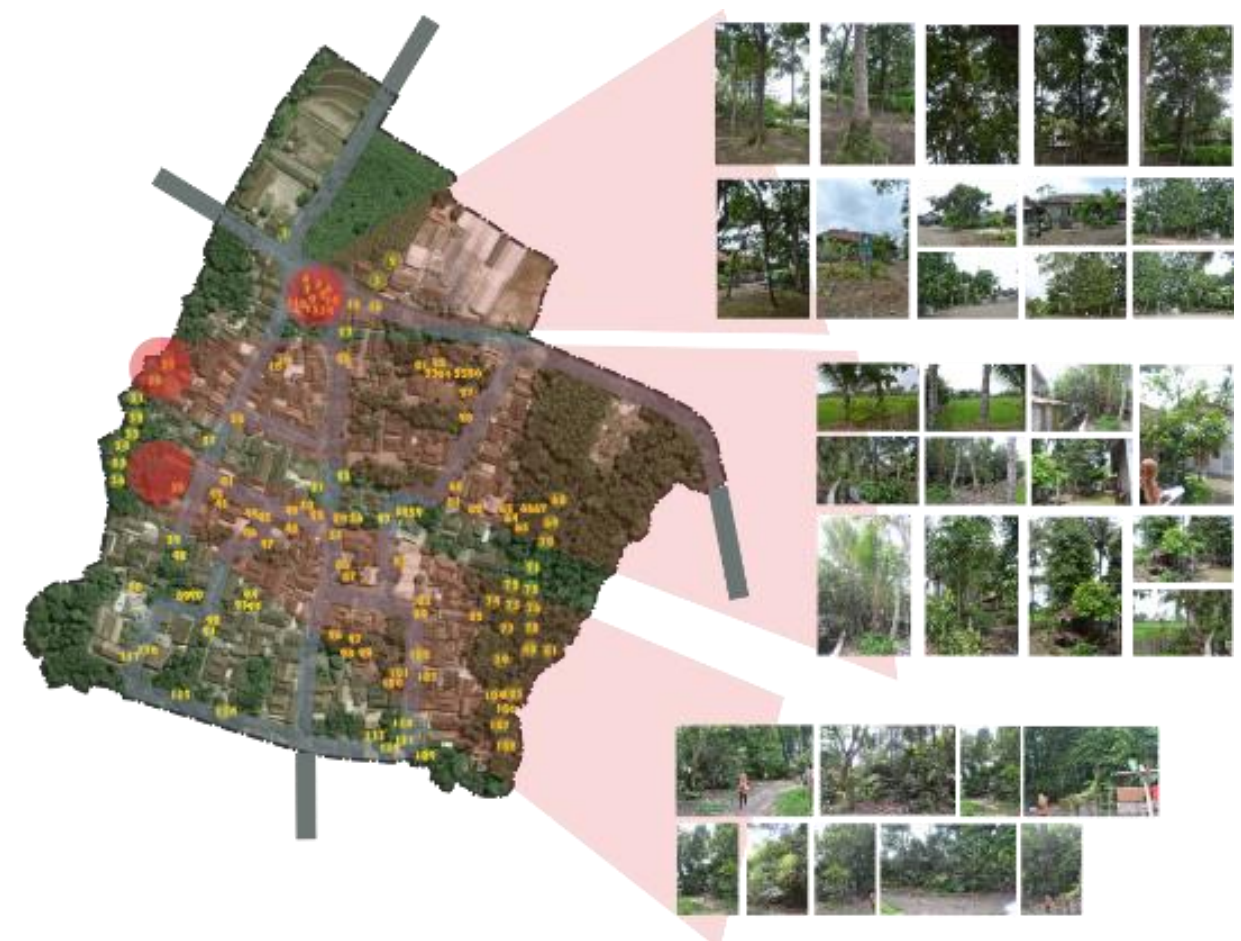

Gambar 6. Peta dusun dari google map yang dimodifikasi.

Kualitas lingkungan dan keadaan fisik termasuk view di Dusun Plalangan terdiri dari sungai, persawahan, perkebunan dan rumah- rumah warga yang khas dengan kolam ikan dan tumbuh-tumbuhan disetiap pekarangan rumahnya.

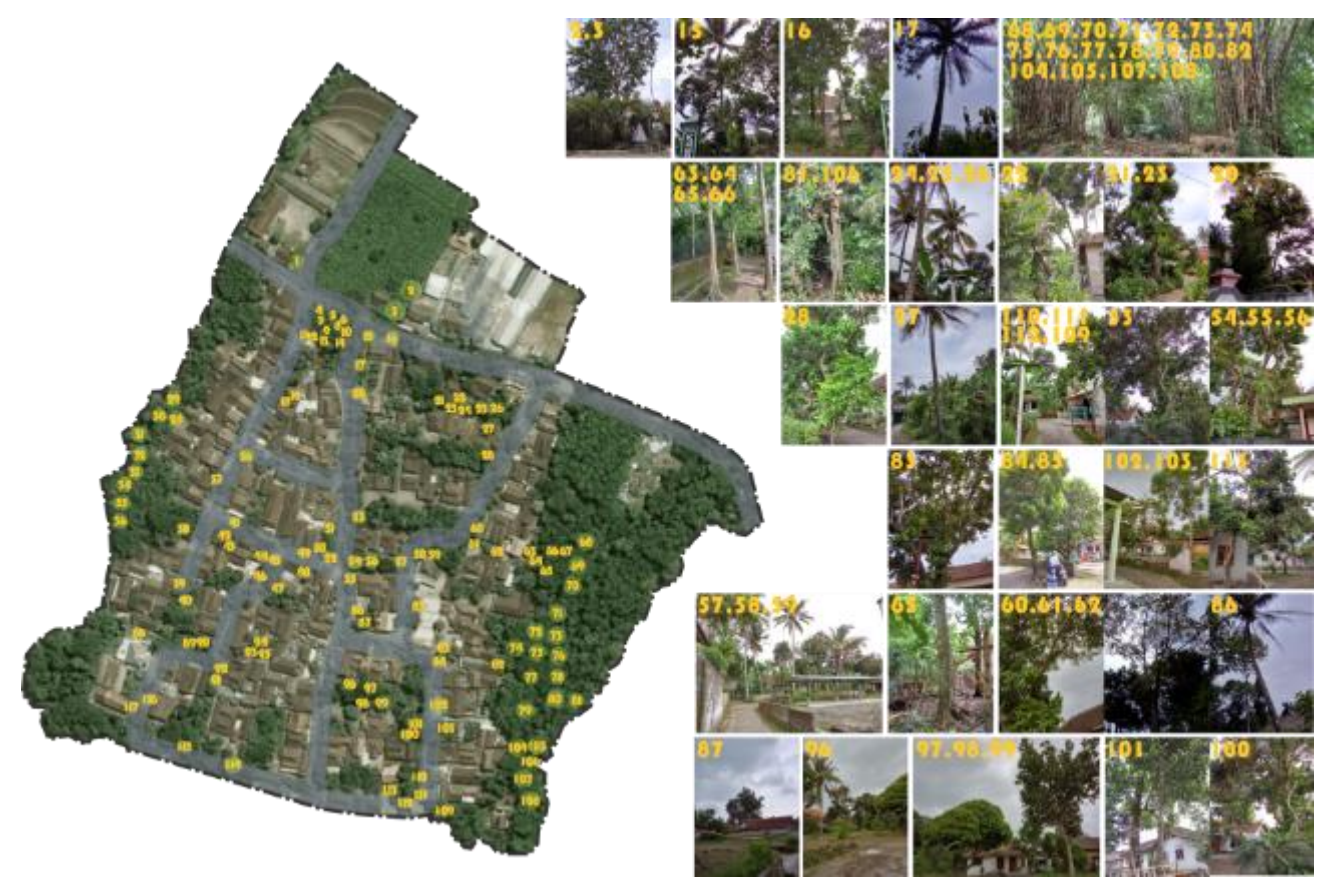

Gambar 7. Peta vegetasi dusun dari google map yang dimodifikasi.

Untuk kepentingan konservasi lingkungan, dilakukan penomeran pohon dilakukan berdasarkan kondisi-kondisi pohon yang ada di dusun Plalangan. Pendataan pohon yang spesifik dan/atau berukuran besar dilakukan agar warga dapat menjaganya dan diharapkan menjadi trademark atau landmark bagi pedusunan dan/atau pedesaan. 


\section{HASIL WAWANCARA DENGAN PAK DUKUH DAN BEBERAPA WARGA PEMBATIK}

Kunjungan dilakukan hari yang sama yaitu hari Senin, 25 Januari 2015 pada pukul 14:00 - 17:00 WIB. Untuk wawancara dengan para warga pembuat batik yang bertujuan mendapatkan informasi-informasi tentang pembuatan dan pengolahan batik secara detail, sehingga menjadi acuan dalam mendesain ruang-ruang bangunan workshop. Dengan begitu informasi-informasi yang diperoleh antara lain adalah ukuran ruang dan furniture tempat pengecapan batik, dimensi tempat pewarnaan, tempat pelorotan serta prosesnya, hingga penjemuran.

Dari hasil wawancara tersebut, tahapan proses membatik sebagai berikut:

- Proses pemanasan malam

- Pencelupan alat cap ke malam

- Pengecapan alat cap yang sudah diisi dengan malam pada kain

- Proses pencoletan

- Proses pewarnaan

- Proses plorotan

- Proses NHCL, yaitu pemunculan warna dasar pada kain

- Proses penjemuran
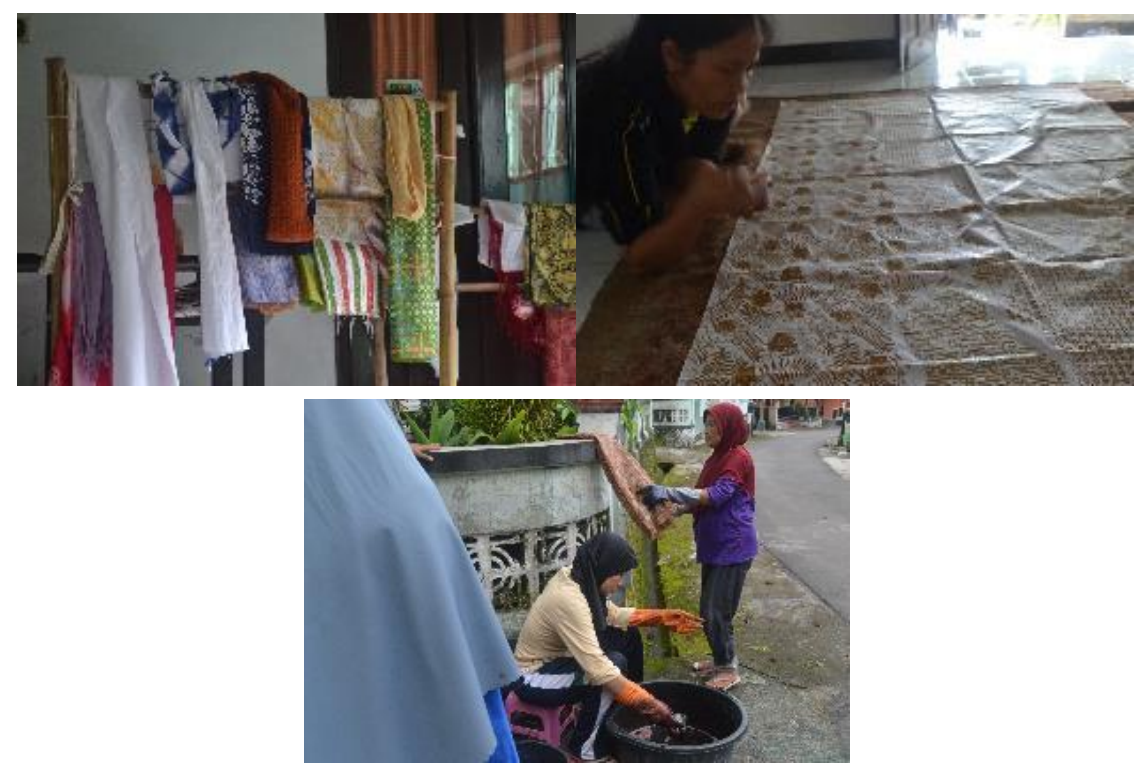

Gambar 8.a. Produk batik Plalangan, b. Proses membatik, c. Proses mencelup dan mewarna

Data inilah yang dijadikan acuan dalam proses mendesain Workshop Batik (lihat lampiran). Kegiatan dilanjutkan dengan kunjungan pada hari Selasa 26 Januari 2016 pada pukul 15:00 - 18:00, dengan tujuan memperoleh informasi-informasi tentang bangunan workhop yang akan di bangun dan informasi data masterplan dusun dengan mewawancarai kepala dusun Plalangan. Kegiatan observasi dilengkapi dengan berkeliling di sekitar dusun untuk melihat potensi-potensi yang ada. Di dusun pelalangan hampir setiap rumah atau kepala keluarga memiliki kolam ikan, hal ini menurut pak Dukuh adalah untuk memenuhi kebutuhan gizi penduduk dengan mengkonsumsi ikan yang dilambangkan sebagai makanan masyarakat sejahtera. Dengan memenuhi kebutuhan masing-masing rumah ini maka setiap rumah telah mandiri dalam memenuhi kebutuhan sehari-harinya. 
Informasi yang didapat setelah survei dengan berkeliling dusun adalah bahwa tanaman-tanaman di setiap pekarangn warga memiliki tujuan untuk memenuhi kebutuhan sehari-hari warga dalam hal makanan sayursayuran dan buah-buahan sehingga tidak lagi bergantung dengan membeli di pasar.

Berikut beberapa poin penting dari hasil wawancara dengan pak Dukuh :

- Konsep dusun Plalangan adalah: Pemanfaatan pekarangan dengan taman buah, sayuran, jamu/obat-obatan dan kolam (terpal).

- Kendaraan pengunjung tidak boleh masuk ke kawasan desa maupun area workshop batik, mereka harus berjalan kaki.

- Workshop batik dan TK dengan ekstrakurikuler batik yang memiliki akses ke workshop batik.

- Potensi aktivitas yang ada di desa akan diperkenalkan, seperti: Annet Sofa (penjual furnitur), tempat menampung warga miskin untuk bekerja, pembuatan getuk, kerajinan keset, pembibitan ikan lele dan lain-lain.

- Pengunjung workshop batik dan wisatawan keliling desa akan tetap transit di rumah ibu Tatik.

- Joglo di depan masjid digunakan sebagai tempat pagelaran acara-acara desa, selain di gedung serbaguna milik desa. Masjid depannya diposisikan sebagai penyempurna (kegiatan tidak pernah lepas dari masjid).

- Direncanakan dibuat area/sentra rumpun bambu di dekat sungai.

- Sirkulasi di dusun Plalangan di desain agar semua setiap rumah bisa terakses.
- Setiap rumah di desa tidak ditandai dengan "Plang" dan tidak di zooning atau dibagibagi, karena tidak ingin mengkotakkotakkan masyarakat.

- Gapura desa "Kampung Plalangan" ada dua, karena desa dapat diakses dari 2 arah utama.

\section{HASIL PENGUKURAN}

Hasil pengukuran ada 4 jenis, yaitu pengukuran ketinggian dan dimensi pohon (ukuran tinggi pohon yang didata rata-rata 12 $\mathrm{m}$, dan diameternya $0.5 \mathrm{~m}$ ), pengukuran lebar sungai, pengukuran jalan-jalan dusun Plalangan dan pengukuran Site yang akan dijadikan sebagai lokasi Worksop Batik. Lebih detail hasil pengukuran dapat dilihat pada gambar 11 dan 12 .

\section{PAPARAN DAN PEMBAHASAN DRAFT DESAIN WORKSHOP DAN MASTERPLAN}

Paparan draft desain workshop dan masterplan dusun Plalangan dilakukan pada hari tanggal pukul 09.00-12.00 WIB di Rumah Batik Ayu Arimbi. Peserta yang hadir adalah perangkat dusun dengan kepala dusunnya, perangkat desa, tokoh masyarakat dan para perajin batik. Hasil paparan draft desain workshop dan masterplan dusun ditanggapi oleh kepala dusun dengan baik, antusias dan memberi masukkan terhadap hasil draft desain workshop dan masterplan dusun, antara lain: konfirmasi lokasi workshop batik dan ukuran lahannya; konfirmasi lokasi gapura dusun berjumlah 2 buah; penomeran pohon-pohon besar dan pemintakatan masing-masing tata ruang berdasar kondisi eksisting. Suasana paparan dan diskusi dapat dilihat pada gambar 9.a., b., dan c. 

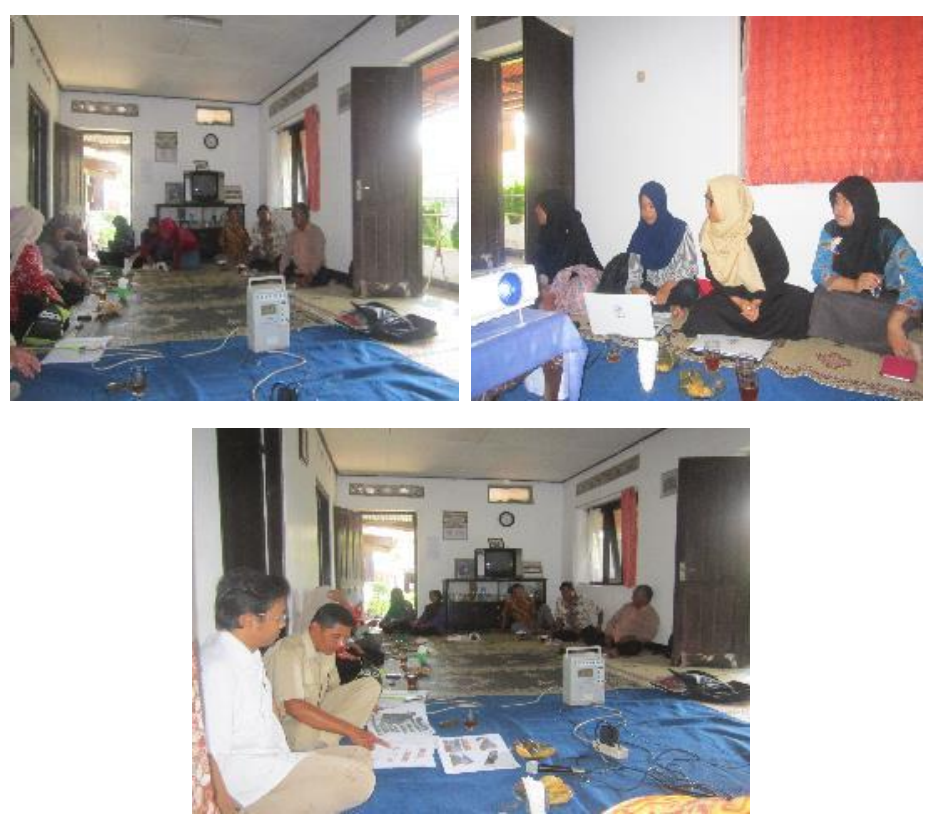

Gambar 9.a.b.c. Suasana paparan dan diskusi

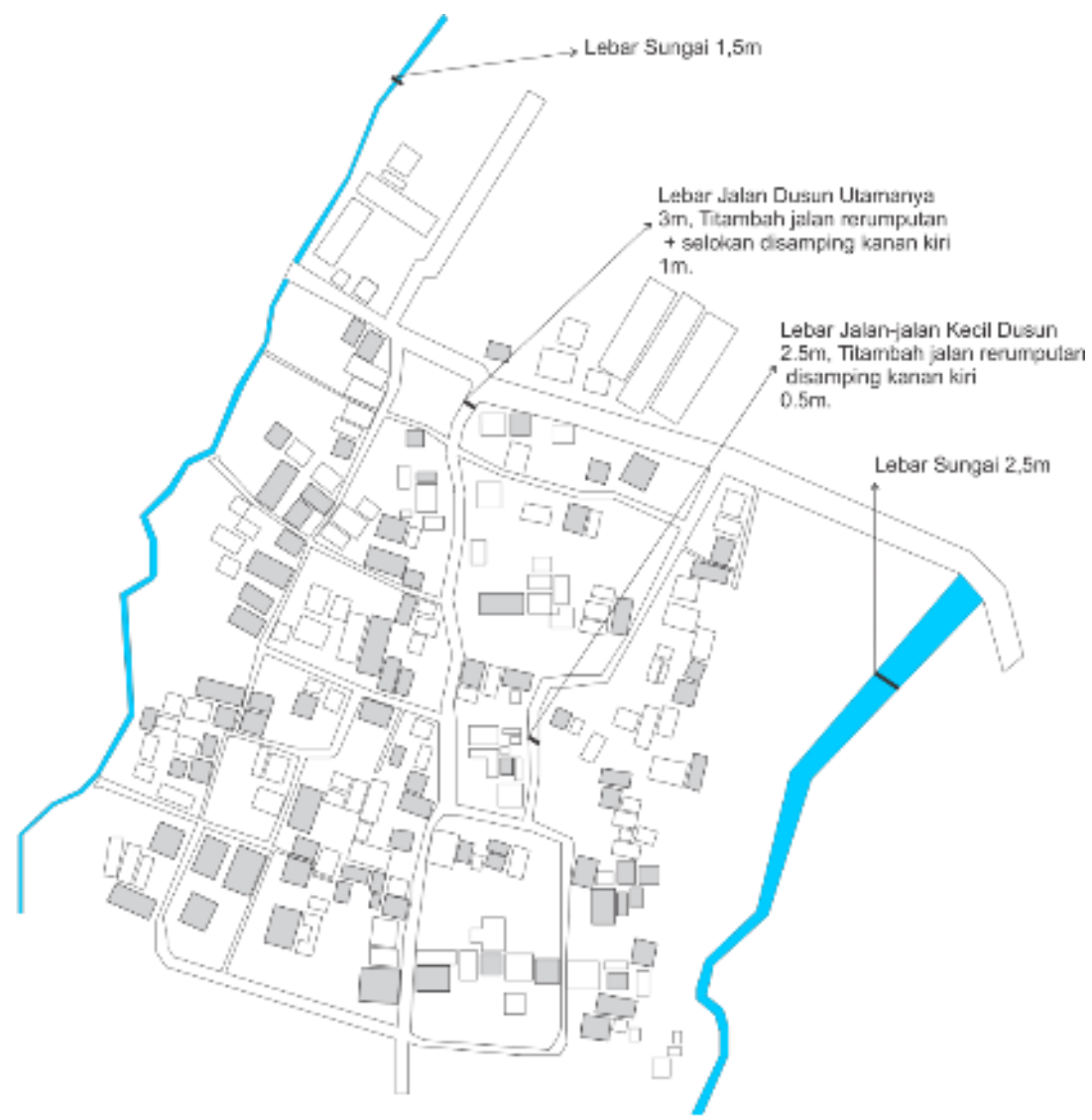

Gambar 10. Peta blok bangunan dan ukuran jalan. 
Prihatmaji,
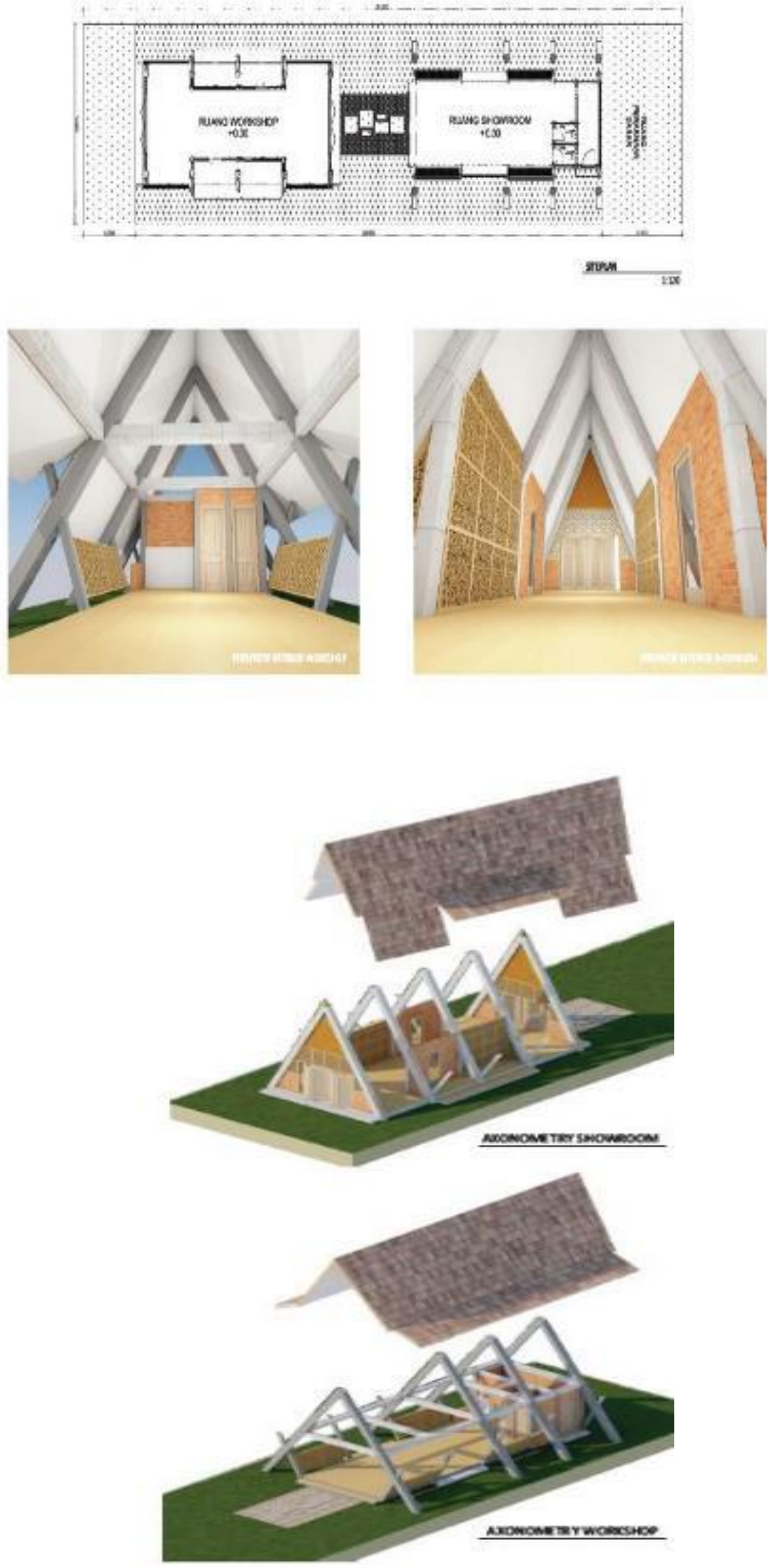

Gambar 11: Hasil Desain Alternatif 04( yang terpilih) 


\section{KESIMPULAN}

Kegiatan pengabdian masyarakat Pendampingan Penyusunan Masterplan Sentra Batik di Dusun Plalangan, Pendowoharjo, Sleman, Yogyakarta kolaborasi antara pusat studi Dukuh Institute, Jurusan Arsitektur Fakultas Teknik Sipil dan Perencanaan Universitas Islam Indonesia dan Dinas Perindustrian, Perdagangan dan Koperasi Kabupaten Sleman telah terlaksana dengan baik. Dari kegiatan yang sudah dilaksakanakan didapat kesimpulan:

1. Warga dusun Plalangan umumnya dan para perajin batik khususnya sangat antusias menyusun informasi Peta Desa yang berisi tata ruang, lokasi titik-titik keunggulan dusun, simpul-simpul produksi batik, informasi lebar jalan, letak pintu gerbang dusun dan letak vegetasi beserta namanya. Dari kegiatan ini dapat diwujudkan perencanaan kawasan dusun secara rinci yang merespon konsekuensi kawasan sentra batik.

2. Masterplan berhasil disusun-kembangkan secara partisipatif dari warga masyarakat dan integratif meliputi aspek tata ruang, lingkungan dan potensi kerajinan batik di dusun. Partisipasi warga tercipta dari koordinasi antar stakeholder perajin batik dan masyarakat dusun yang memungkinkan untuk dikembangkan sebagai data kebutuhan sentra batik. Sumber daya manusia setempat dilibatkan dalam memetakan potensi kawasan dusun dan penyusunan masterplan dusun sebagai kawasan sentra batik.

\section{UCAPAN TERIMAKASIH}

Ucapan terimakasih disampaikan kepada Direktorat Penelitian dan Pengabdian Masyarakat Universitas Islam Indonesia (DPPM UII) yang telah membiayai kegiatan pengabdian kepada masayarakat ini ini hingga purna dilaksanakan. Ucapan terimakasih juga disampaikan pada mahasiswa Prodi Arsitektur 165
(Hendra Juma OS, Lu'luil

Ma'nun, Amira Rasyida Sarah, dan Nidaul Husna) yang telah membantu dalam pelaksanaan kegiatan pengabdian pada masyarakat ini. Selain itu ucapan terimakasih juga disampaikan kepada masyarakat Dusun Plalangan Pendowoharjo Sleman yang telah membantu dalam pelaksanaan pengabdian ini. Semoga hasil pengabdian ini bermanfaat khususnya bagi pengembangan desa mitra DPPM UII dan umumnya bagi semua masyarakat akademis dan masyarakat umum.

\section{DAFTAR PUSTAKA}

Maksudin, 2001, Strategi Pengembangan Potensi dan Program Desa Binaan/Mitra Kerja IAIN Sunan Kalijaga Yogyakarta, Jurnal Aplikasia, Vol.2 No.2 Edisi Desember 2001, P2M IAIN Sunan Kalijaga Yogyakarta.

Margono Slamet, 1993,"Arti dan

Metode

Pengabdian pada Masyarakat dan bentuk- bentuk pelaksanaannya oleh Perguruan Tinggi", dalam Agussalim Sitompul (ed), Metodologi Pengabdian pada Masyarakat, Yogyakarta: P2M IAIN Sunan Kalijaga Yogyakarta. 